\title{
TRANSFORMASI HOUGH LINEAR UNTUK ANALISIS DAN PENGENALAN BATIK MOTIF PARANG
}

\author{
Widi Hapsari ${ }^{1}$ \\ widi@staff.ukdw.ac.id
}

\begin{abstract}
Batik is a craft that has high artistic value. Batik also has become part of Indonesian culture (especially Java) since long. There are so many designs old patterns of Batik. One of traditional batik motif is Parang. Batik Parang have decorative striped pattern and lined tilted. This research analizes characteristic of batik Parang and develops a software to automatically identify motifs of batik Parang image using line feature extraction. The pattern can be identified through a group of points that form the edge of a line and then detected as a line using Hough transform. The research material was 50 image of the sample data and 30 image of research datarespectivelyParang and non Parang. Both the accuracy of Batik Parang and non Parang recognition are 90\%.
\end{abstract}

Keywords: Canny, Hough Transform, Batik Parang

\section{Pendahuluan}

Batik merupakan warisan budaya Indonesia. Masih banyak masyarakat yang masih belum mampu mengenali motif-motif batik yang ada. Batik memiliki motif yang berbeda pada setiap daerah termasuk di Yogyakarta. Motif adalah desain secara keseluruhan dari kain batik. Sementara ornamen adalah bentuk objek yang berfungsi sebagai penghias atau pengisi. Minat batik belum diimbangi dengan pemahaman tentang batik itu sendiri (Kusrianto, 2013). Ada banyak motif batik, dan yang terkenal di Yogyakarta antara lain batik Parang, Semen, Nitik dan Ceplok (Dinas Perindustrian Perdagangan dan Koperasi DIY, 2007), (Dinas Perindustrian Perdagangan dan Koperasi DIY, 2007), (Dinas Perindustrian Perdagangan dan Koperasi DIY, 2007), (Dinas Perindustrian Perdagangan dan Koperasi DIY, 2007).Setiap motif memiliki ciri khas tertentu yang merupakan identitas motif tersebut. Misalnya motif Parang yaitu motif batik yang mempunyai pola hias bergaris miring dan berjajar (Dinas Perindustrian Perdagangan dan Koperasi DIY, 2007).

Sebagai bentuk keperdulian terhadap salah satu warisan budaya Yogyakarta,maka penelitian ini dilakukan agar masyarakat dapat mengenalimotif batik. Penelitian ini mengambil salah satu motif yaitu motif Parang. Dengan ciri yang dimiliki motif tersebut, maka dipilih metode yang mampu mengidentifikasi garis. Pengenalan Parang secara digital ini dapat dilakukan dengan metode Linear Hough Transform untuk mengenali garis lurus.Transformasi Houghdapat digunakan untuk mendeteksi bentuk-bentuk sembarang (Ballard, 1981). Beberapa contoh penggunaan transformasi Hough untuk pengenalan objek pada citra telah dilakukan oleh Yu-Tai Ching (Yu-Thai, 2001), dan Mahmood (Mahmood \& Mansur, 2012). Dalam penelitian ini Linear Hough Transform digunakan untuk mengenali motif Parang yang memiliki pola garis miring sebagai ciri khasnya. Pada penelitian ini dilakukan analisis terhadap karakteristik terhadap motif Parang dari sebaran garis pada sudut kemiringan tertentu dan panjang garis dalam kelompok kemiringan sudut. Penelitian dilanjutkan dengan membangun sebuah sistem untuk melakukan pengenalan berdasarkan hasil analisis tersebut terhadap data inputcitra motif batik. Dari citra input tersebut apakah dikenali sebagai Parang atau tidak.

\footnotetext{
${ }^{1}$ Program Studi Teknik Informatika, Universitas Kristen Duta Wacana, Yogyakarta
} 


\section{Landasan Teori}

\subsection{Tinjauan Pustaka}

Johanes Widagdho Yodha, Achmad Wahid Kurniawan melakukan penelitian Pengenalan Motif Batik menggunakan deteksi tepi Canny dan K-Nearest Neighbor. Dataset yang digunakan berjumlah 300, yang terbagi menjadi dataset trainingdan dataset testing. Dataset training secara bertahap menggunakan jumlah 210 citra, 240 citra dan 270 citra denganjumlah kelas yaitu 6 kelas. Dataset testing menggunakan 30 citra dengan menggunakan jumlah kelas yang sama. Preprocessing yang digunakan adalah resize, grayscale, histogram equalization dan deteksi tepi Canny. Untuk metode klasifikasi menggunakan K-NN. Hasil akurasi pengenalan yang diperoleh dari masing-masing data training yang digunakan berturut-turut : 56,67\%, 66,67\%, 66,67\% (Yodha \& Kurniawan, 2014).

A Haris Rangkuti pada penelitian Klasifikasi Motif Batik Berbasis Kemiripan Ciri dengan Wavelet Transform dan Fuzzy Neural Network. Dalam penelitiannya urutan langkah yang dilakukan adalah preprocessing, transformasi wavelet dengan daubechies 2 level 2, pengambilan 3 fitur yaitu mean, standar deviasi dan energi, pembangunan rule untuk klasifikasi dengan menggunakan Fuzzy Neural Network. Hasil akurasi dari penelitian ini sebesar 86\%-92\% (Rangkuti, 2014).

Penelitian untuk klasifikasi K-Nearest Neighbor pada batik yogya motif Parang, Ceplok, Nitik, dan Semen juga pernah dilakukan oleh Angesti et.al (Angesti, 2015) dengan menggunakan fitur momen invariant, oleh Hartono et.al dengan menggunakan Wavelet Daubechies (Hartono, Haryono, \& Hapsari, 2015), dan oleh Stefanny et.al (Felixiana, 2015).

\subsection{Deteksi Tepi Canny}

Preprocessing pada penelitian ini dilakukan dengan menggunakan deteksi tepi Canny. Sebuah tepi dapat diperoleh dari perubahan pencahayaan pada pixel yang bersebelahan. Operator Canny didesain untuk mendapatkan deteksi tepi yang optimal. Canny bekerja dengan beberapa tahap proses (Canny, 1986), (Douugherty, 2009), (Russ, 2011). Algoritma deteksi tepi Canny terdiri dari langkah-langkah berikut:

a. Mengurangi noise pada citra dengan menggunakan Gaussian Smoothing

b. Menghitung vektor magnitude dan arah (gradien) untuk mendapatkan garis

c. Menipiskan garis dengan melakukan supresi non-maxima

d. Gunakan analisis double thresholding and connectivity untuk mendeteksi dan menghubungkan tepi

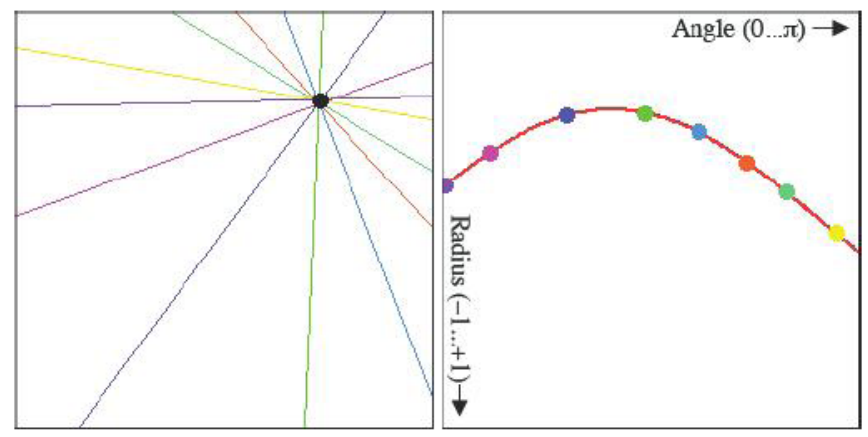

(a)

(b)

Gambar 1. Prinsip Transformasi Hough

(Russ, 2011)

\subsection{Transformasi Hough}

Beberapa prinsip yang dilakukan pada Hough Transform adalah:(a) untuk setiap titik pada gambar dalam bidang-xy akan membentuk sebuah kurva sinusoidal di dalam ruang Hough (r, 
$\theta$ ). (b) setiap garis yang melalui suatu titik yang sama dalam bidang-xy merupakan titik-titik penyusun sebuah kurva sinusoidal di dalam ruang Hough. Titik-titik perpotongan di dalam ruang Hough mengidentifikasi garis-garis di dalam bidang-xy seperti diperlihatkan dalam Gambar 1. (Russ, 2011)

\section{Metodologi Penelitian}

Dalam penelitian ini data dan proses dijelaskan sebagai berikut.

\subsection{Pengambilan data}

Proses pengambilan data dilakukan dalam 2 tahap. Tahap pertama untuk identifikasi batik Parang. Dalam hal ini menggunakan 50 gambar batik Parang. Tahap kedua dilakukan untuk pengujian dengan menggunakan 30 gambar batik parang yang berbeda dengan gambar pada tahap pertama, dan 30 gambar batik non Parang. Dari data yang diambil dilakukan proses normalisasi dengan membuat ukuran gambar menjadi 256x256.

\subsection{Analisis Karakteristik Motif Parang}

Untuk menganalisis motif Parang maka dilakukan beberapa proses secara berurutan yaitu:resize,grayscale, black white, deteksi tepi Canny, dan transformasiHough. Dari garisgaris hasil transformasi Hough diamati karakteristik batik parang seperti sudut kemiringan garis, garis terpanjang, dan rata-rata panjang garis minimal. Diagram proses analisis ditunjukkan melalui diagram pada Gambar 2.

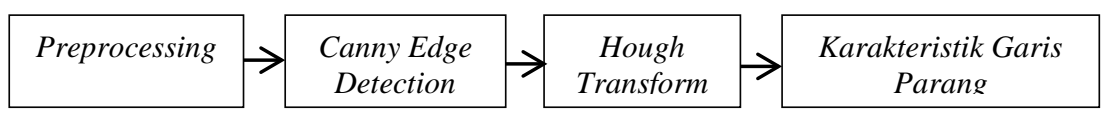

Gambar 2. Diagram proses Analisis

\subsection{Pembuatan Sistem Pengenalan}

Dari hasil analisis karakteristik yang diperoleh dari tahap analisis maka dibuat sistem pengenalan yang menguji input citra batik apakah termasuk Parang atau tidak. Dalam sistem ini suatu input citra batik dikategorikan sebagai Parang jika garis-garis yang diperoleh dari transformasi Hough memenuhi hal-hal berikut : sebagian besar garis berada dalam kemiringan tertentu, minimal garis terpanjang di atas nilai tertentu, dan rata-rata panjang garis minimal berada dalam kisaran nilai tertentu.

\subsection{Pengujian keberhasilan sistem}

Untuk menguji tingkat keberhasilan sistem digunakan 30 data Parang yang lain di luar data parang untuk tahap identifikasi, dan 30 data non Parang. Ukuran keberhasilan menggunakan nilai tingkat pengenalan seperti yang diberikan dalam Persamaan [1].

$$
\text { Tingkat Pengenalan }=\frac{\text { jumlah pengujian yang benar }}{\text { Total Data } \text { uji }}
$$

\section{Hasil Penelitian}

Penelitian ini melalui dalam tiga tahap, yaitu tahap analisis karakteristik, tahap pembuatan sistem pengenalan berbasis karakeristik, dan tahap pengujian dengan hasil yang diperoleh diberikan berikut ini. 


\subsection{Tahap Analisis Karakteristik}

Tahap ini dilakukan dengan menggunakan data 50 motif Parang yang sudah melalui preprocessingdan deteksi tepiCanny. Dalam tahap ini, pertama kali diamati karakteristik kemiringan garis-garis dari batik parang hasil transformasi Hough. Hasil pengamatan diperoleh bahwa garis-garis lurus yang dideteksi menggunakan transformasi Hough berada di dalam sudut kemiringan theta antara $-20^{\circ}$ sampai dengan $-70^{\circ}$ (sektor A) atau berada di antara $20^{\circ}$ sampai dengan $70^{\circ}$ (sektor B) seperti yang ditandai dengan warna putih yang diberikan dalam Gambar 3. Pemilihan sudut ini didasarkan pada jumlah garis yang termuat.

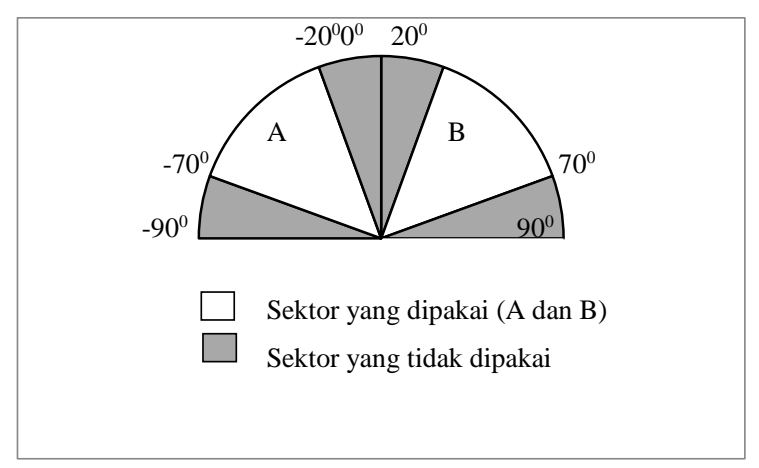

Gambar 3. Sudut pembagian sektor

Penelitian dilanjutkan dengan mengamati karakteristik garis-garis Parang yang berada di dalam tiap-tiap sektor dengan hasil yang diperoleh adalah:

a) Nilai garis terpanjang yang berada di dalam sektor A atau sektor B minimal 80 .

b) Nilai rata-rata panjang garis yang berada pada sektor A atau B adalah 50 .

Hasil pengamatan dari 50 Parang inilah yang dipakai sebagai dasar pembuatan sistem pengenalan batik motif Parang.

\subsection{Pembuatan Sistem Pengenalan Parang}

Sistem dibuat dengan melakukan beberapa proses preprocessing yang sama dengan tahap identifikasi. Dalam preprocessing ini dipakai library matlab imrezise, rgb2gray, im2bw dan canny. Hasil deteksi tepi Canny dilakukan transformasi Hough untuk memperoleh garis-garis yang ada di dalam gambar. Parameter yang dipakai di dalam transformasi Hough adalah :

a) Minimum panjang garis yang diakui sebagai garis adalah 15 (MinLength).

b) Maksimum jarak 2 garis yang dianggap berbeda adalah 15 pixel (FillGap).

Setiap garis dikelompokkan berdasarkan nilai sudut theta untuk dimasukkan ke dalam sektor A, sektor B atau tidak keduanya. Selanjutnya dilakukan perhitungan untuk garis terpanjang dan rata-rata panjang garis untuk setiap sektor.

\subsection{Hasil Pengujian Sistem}

Dalam pengujian ini digunakan motif batik Parang yang lainnya sebanyak 30 gambar, dan motif batik non Parang sebanyak 30 gambar. Hasil pengujian batik Parang diberikan dalam Tabel 1.

Tabel 1.

Hasil Pengujian Motif Parang

\begin{tabular}{|c|c|c|c|c|c|c|}
\hline \multirow{2}{*}{$\begin{array}{c}\text { Nomor } \\
\text { Gambar }\end{array}$} & \multicolumn{2}{|c|}{ A (-20< $<$ theta $<=-\mathbf{7 0 )}$} & \multicolumn{2}{c|}{ B $(\mathbf{2 0}<$ theta $<=\mathbf{7 0})$} & \multicolumn{2}{c|}{ Selain sektor A dan B } \\
\cline { 2 - 7 } & max_len & rerata & max_len & rerata & max_len & rerata \\
\hline 1 & 70,4 & 38,2 & 0,0 & 0,0 & 8,0 & 6,1 \\
\hline 2 & 132,0 & 66,1 & 0,0 & 0,0 & 0,0 & 0,0 \\
\hline
\end{tabular}




\begin{tabular}{|c|c|c|c|c|c|c|}
\hline \multirow{2}{*}{$\begin{array}{c}\text { Nomor } \\
\text { Gambar }\end{array}$} & \multicolumn{2}{|c|}{ A $(-20<$ theta $<=-70)$} & \multicolumn{2}{|c|}{ B $(20<$ theta $<=70)$} & \multicolumn{2}{|c|}{ Selain sektor A dan B } \\
\hline & max_len & rerata & max_len & rerata & max_len & rerata \\
\hline 3 & 0,0 & 0,0 & 96,5 & 57,8 & 6,1 & 5,1 \\
\hline 4 & 102,4 & 48,7 & 0,0 & 0,0 & 0,0 & 0,0 \\
\hline 5 & 0,0 & 0,0 & 178,5 & 99,5 & 20,8 & 14,6 \\
\hline 6 & 193,7 & 77,2 & 0,0 & 0,0 & 0,0 & 0,0 \\
\hline 7 & 104,6 & 64,8 & 0,0 & 0,0 & 8,6 & 8,3 \\
\hline 8 & 116,8 & 44,6 & 0,0 & 0,0 & 0,0 & 0,0 \\
\hline 9 & 272,4 & 172,1 & 0,0 & 0,0 & 0,0 & 0,0 \\
\hline 10 & 198,5 & 111,2 & 0,0 & 0,0 & 0,0 & 0,0 \\
\hline 11 & 162,9 & 60,1 & 0,0 & 0,0 & 0,0 & 0,0 \\
\hline 12 & 0,0 & 0,0 & 250,0 & 87,5 & 0,0 & 0,0 \\
\hline 13 & 0,0 & 0,0 & 116,5 & 72,6 & 30,3 & 14,8 \\
\hline 14 & 107,0 & 47,8 & 0,0 & 0,0 & 21,8 & 21,8 \\
\hline 15 & 176,2 & 89,4 & 0,0 & 0,0 & 0,0 & 0,0 \\
\hline 16 & 182,3 & 98,1 & 0,0 & 0,0 & 0,0 & 0,0 \\
\hline 17 & 0,0 & 0,0 & 68,9 & 41,5 & 13,0 & 13,0 \\
\hline 18 & 0,0 & 0,0 & 252,7 & 209,3 & 0,0 & 0,0 \\
\hline 19 & 224,2 & 69,7 & 0,0 & 0,0 & 0,0 & 0,0 \\
\hline 20 & 105,6 & 56,7 & 0,0 & 0,0 & 0,0 & 0,0 \\
\hline 21 & 185,6 & 79,3 & 0,0 & 0,0 & 0,0 & 0,0 \\
\hline 22 & 0,0 & 0,0 & 121,7 & 54,7 & 0,0 & 0,0 \\
\hline 23 & 219,8 & 72,2 & 0,0 & 0,0 & 0,0 & 0,0 \\
\hline 24 & 145,5 & 44,6 & 46,1 & 26,1 & 12,5 & 11,0 \\
\hline 25 & 247,1 & 211,3 & 0,0 & 0,0 & 0,0 & 0,0 \\
\hline 26 & 208,9 & 54,4 & 0,0 & 0,0 & 0,0 & 0,0 \\
\hline 27 & 84,7 & 54,5 & 53,0 & 30,7 & 0,0 & 0,0 \\
\hline 28 & 74,9 & 42,2 & 0,0 & 0,0 & 0,0 & 0,0 \\
\hline 29 & 87,2 & 46,8 & 40,3 & 32,3 & 18,0 & 13,7 \\
\hline 30 & 0,0 & 0,0 & 142,8 & 60,2 & 0,0 & 0,0 \\
\hline
\end{tabular}

Dari Tabel 1 diperoleh tingkat pengenalan sebesar 90\%, dengan tiga gambar batik Parang yang salah adalah gambar nomor 1, 17 dan 28. Dari pengamatan, gambar-gambar yang gagal dikenali karena detil dari Parang ikut teridentifikasi, sehingga hasil deteksi tepi tidak membentuk garis lurus. Sedangkan gambar yang lain karena faktor pencahayaan yang tidak merata, sehingga hasil deteksi tepi di tengah gambar cenderung tidak teridentifikasi. Hasil penelitian dengan menggunakan 30 batik non parang diberikan dalam Tabel 2.

Tabel 2.

Contoh Pengujian Motif non Parang

\begin{tabular}{|r|r|r|r|r|c|c|}
\hline $\begin{array}{c}\text { Nomor } \\
\text { Gambar }\end{array}$ & \multicolumn{2}{|c|}{ A (-20 < theta <= -70) } & \multicolumn{2}{c|}{ B (20 < theta <= 70) } & \multicolumn{2}{c|}{ Selain sektor A dan B } \\
\cline { 2 - 7 } & max_len & \multicolumn{1}{l|}{ rerata } & max_len & \multicolumn{1}{l|}{ rerata } & max_len & rerata \\
\hline 1 & 0,0 & 0,0 & 0,0 & 44,8 & 22,4 & 15,5 \\
\hline 2 & 60,1 & 44,6 & 2,0 & 59,4 & 44,5 & 30,8 \\
\hline 3 & 61,6 & 32,5 & 12,0 & 21,6 & 0,0 & 0,0 \\
\hline
\end{tabular}




\begin{tabular}{|c|c|c|c|c|c|c|}
\hline \multirow{2}{*}{$\begin{array}{l}\text { Nomor } \\
\text { Gambar }\end{array}$} & \multicolumn{2}{|c|}{ A $(-20<$ theta $<=-70)$} & \multicolumn{2}{|c|}{ B $(20<$ theta $<=70)$} & \multicolumn{2}{|c|}{ Selain sektor A dan B } \\
\hline & max_len & rerata & max_len & rerata & max_len & rerata \\
\hline 4 & 0,0 & 0,0 & 0,0 & 0,0 & 46,9 & 24,2 \\
\hline 5 & 29,4 & 23,1 & 6,0 & 49,5 & 4,0 & 3,9 \\
\hline 6 & 66,5 & 28,0 & 11,0 & 40,3 & 0,0 & 0,0 \\
\hline 7 & 0,0 & 0,0 & 0,0 & 0,0 & 9,9 & 9,7 \\
\hline 8 & 25,5 & 20,0 & 9,0 & 20,5 & 0,0 & 0,0 \\
\hline 9 & 63,6 & 29,6 & 8,0 & 57,3 & 0,0 & 0,0 \\
\hline 10 & 0,0 & 0,0 & 0,0 & 0,0 & 40,3 & 27,2 \\
\hline 11 & 90,0 & 90,0 & 1,0 & 0,0 & 29,5 & 22,3 \\
\hline 12 & 40,3 & 27,2 & 8,0 & 20,8 & 0,0 & 0,0 \\
\hline 13 & 0,0 & 0,0 & 0,0 & 87,5 & 13,3 & 12,8 \\
\hline 14 & 73,6 & 39,6 & 3,0 & 161,9 & 20,8 & 19,3 \\
\hline 15 & 22,0 & 20,9 & 3,0 & 0,0 & 24,8 & 15,9 \\
\hline 16 & 15,6 & 15,6 & 2,0 & 16,3 & 0,0 & 0,0 \\
\hline 17 & 59,2 & 41,2 & 3,0 & 0,0 & 38,8 & 27,5 \\
\hline 18 & 69,5 & 37,4 & 5,0 & 50,2 & 8,3 & 5,4 \\
\hline 19 & 0,0 & 0,0 & 0,0 & 0,0 & 13,1 & 10,9 \\
\hline 20 & 0,0 & 0,0 & 0,0 & 0,0 & 46,5 & 29,2 \\
\hline 21 & 0,0 & 0,0 & 0,0 & 36,9 & 23,8 & 20,3 \\
\hline 22 & 69,3 & 27,8 & 8,0 & 43,1 & 0,0 & 0,0 \\
\hline 23 & 31,8 & 26,1 & 7,0 & 26,4 & 0,0 & 0,0 \\
\hline 24 & 0,0 & 0,0 & 0,0 & 0,0 & 37,5 & 17,2 \\
\hline 25 & 46,0 & 31,8 & 3,0 & 63,8 & 44,0 & 27,6 \\
\hline 26 & 0,0 & 0,0 & 0,0 & 26,2 & 43,0 & 18,8 \\
\hline 27 & 15,6 & 15,6 & 6,0 & 41,0 & 0,0 & 0,0 \\
\hline 28 & 56,6 & 43,6 & 7,0 & 0,0 & 15,3 & 8,4 \\
\hline 29 & 0,0 & 0,0 & 0,0 & 0,0 & 63,8 & 30,1 \\
\hline 30 & 65,8 & 36,4 & 8,0 & 34,7 & 23,0 & 20,1 \\
\hline
\end{tabular}

Dari Tabel 2 diperoleh tingkat pengenalan non Parang juga sebesar 90\%, dengan tiga gambar batik non Parang yang dikenali sebagai Parang adalah gambar nomor 11, 13, dan 14.

\section{Kesimpulan}

Batik Parang dapat dikenali dengan menggunakan transformasi garis Hough dengan karakteristik sebagian besar garis berada dalam sektor A $\left(-20^{\circ}<\right.$ Theta $\left.<=70^{\circ}\right)$ atau sektor B $\left(20^{\circ}<\right.$ Theta $\left.<=70^{\circ}\right)$. Dengan panjang minimal garis terpanjang 80 , dan rata-rata panjang garis minimal 50. Sistem Pengenalan motif Parang dengan menggunakan transformasi Hough untuk mendeteksi garis dengan parameter panjang garis dan nilai theta yang telah dibuat memberikan nilai akurasi sebesar 90\%. Hasil ini lebih bagus dibandingkan dengan hasil penelitian dari Angesti dalam mengenali Parang sebesar 87,5\% dengan preprocessing opening menggunakan fitur momen invariant Hu (Angesti, 2015), Felixiana untuk mengenali Parang sebesar 87,5\% dengan dengan preprocessing opening menggunakan fitur Eccentricity (Felixiana, 2015). Juga lebih bagus dibandingan penelitian Hartono yang mengenali Parang 62,5\% dengan 
menggunakan Wavelet Daubechies orde 4 level 2 berbasis bentuk (Hartono, Haryono, \& Hapsari, 2015).

\section{Daftar Pustaka}

Angesti, A. (2015). Klasifikasi Motif Batik Menggunakan Moment Invariants. Skripsi, Universitas Kristen Duta Wacana, Teknik Informatika, Yogyakarta.

Ballard, D. H. (1981). Generalizing The Hough Transform To Detect Arbitary Shape. Pattern Recognition , 13 (2), 111-122.

Canny, J. (1986). A Computatioal Approach to Edge Detection. IEEE TRANSACTIONS ON PATTERN ANALYSIS AND MACHINE INTELLIGENCE , 8 (6), 679-698.

Dinas Perindustrian Perdagangan dan Koperasi DIY. (2007). Buku Motif Batik Yogya Ceplok (1 ed.). Yogyakarta, Indonesia: Pena Persada Desktop Publishing.

Dinas Perindustrian Perdagangan dan Koperasi DIY. (2007). Buku Motif Batik Yogya Nitik (1 ed.). Yogyakarta, Indonesia: Pena Persada Desktop Publishing.

Dinas Perindustrian Perdagangan dan Koperasi DIY. (2007). Buku Motif Batik Yogya Parang dan Lereng (1 ed.). Yogyakarta, Indonesia: Pena Persada Desktop Publishing.

Dinas Perindustrian Perdagangan dan Koperasi DIY. (2007). Buku Motif Batik Yogya Semen (1 ed.). Yogyakarta, Indonesia: Pena Persada Desktop Publishing.

Douugherty, G. (2009). Digital Image Processing for Medical Application. New York: Cambridge University Press.

Felixiana, S. (2015). Klasifikasi Batik Menggunakan K-Nearest Neighbour Berbasis Nilai Eccentricity dan Compactness. Skripsi, Universitas Kristen Duta Wacana, Teknik Informatika, Yogyakarta.

Hartono, E. S., Haryono, N. A., \& Hapsari, W. (2015). Klasifikasi Motif Batik Berbasis Representasi Bentuk dengan Metode Wavelet Daubechies. Skripsi, Universitas Kristen Duta Wacana, Teknik Informatika, Yogyakarta.

Kusrianto, A. (2013). Batik Filosofi, Motif dan Kegunaan. Yogyakarta: Andi.

Mahmood, N. H., \& Mansur, M. A. (2012). Red Blood Cells Estimation using Hough Transform Technique : An International Journal (SIPIJ). Signal and Image Processing , 3 (2), 53-64.

Rangkuti, A. H. (2014). Klasifikasi Motif Batik Berbasis Kemiripan Ciri dengan Wavelet Transform dan Fuzzy Neural Network. ComTech, 361-372.

Russ, J. C. (2011). The Image Processing Handbook. India: CRC Press Taylor \& Francis Group.

Yodha, J. W., \& Kurniawan, A. W. (2014). Pengenalan Motif Batik Menggunakan Deteksi Tepi Canny dan K-Nearest Neighbor. Techno.COM , 251-262.

Yu-Thai, C. (2001). Detecting line segments in an image - a new implementation for Hough Transform. Pattern Recognition Letters , 22 (3-4), 421-429. 